\title{
Upaya Meningkatkan Kemampuan Berbicara Bahasa Inggris dalam Percakapan Sehari-Hari dengan Metode VAK (Visualization, Auditory, Kinestetic) bagi Para Santri Pondok Pesantren Nurul Huda 2 Tanah Merah
}

\author{
Zulaikah \\ STKIP Nurul Huda Sukaraja \\ E-mail: zulaikah@stkipnurulhuda.ac.id
}

INFO ARTIKEL ABSTRAK

Available online

DOI:

https://journal.stkipnurulhuda.ac.id/ index.php/JIMi/article/view/420

\section{How to cite (APA): \\ Penulis, N. (2018). JudulArtikel. Jurnal Indonesia Mengabdi, 1(1), 1-4. \\ Zulaikah, Z. (2019). Upaya Meningkatkan Kemampuan Berbicara Bahasa Inggris dalam Percakapan Sehari-Hari dengan Metode VAK (Visualization, Auditory, Kinestetic) bagi Para Santri Pondok Pesantren Nurul Huda 2 Tanah Merah. Jurnal Indonesia Mengabdi, 1(1), 6-10}

This work is licensed under a Creative Commons Attribution 4.0 International License

\begin{abstract}
Abstrak
Salah satu tujuan utama dari mempelajari bahasa Inggris di era globalisasi saat ini adalah kemampuan dalam percakapan bahasa Inggris. Namun, kemampuan percakapan bahasa Inggris masih dianggap sebagai salah satu keterampilan yang sulit dilakukan bagi santri yang ada dipondok pesatren Nurul Huda 2 Tanah Merah. Banyak santri menghadapi beberapa kesulitan ketika mereka ingin berkomunikasi dengan bahasa Inggris, meskipun mereka telah mempelajari bahasa Inggris bertahun-tahun lamanya. Sebagai solusi untuk memberikan motivasi santri belajar dan berkomunikasi dengan bahasa Inggris yaitu dengan menyediakannya media pengajaran yang menarik melalui metode pembelajaran yang efektif. Pada pengabdian ini metode yang digunakan adalah dengan menggunakan media VAK (Visualization, Auditory, and Kinestetic). Hasil dan manfaat dari kegiatan pengabdian ini salah satunya adalah memberikan pengetahuan tentang media dan metode pembelajaran percakapan bahasa Inggris untuk meningkatkan minat santri dalam belajar dan berkomunikasi dengan bahasa Inggris setiap harinya.

Kata kunci: Kemampuan Berbicara, Visualization Auditory Kinestetic.
\end{abstract}

\begin{abstract}
One of the main objectives of learning English in the current era of globalization is ability in English conversation. However, English conversation skills are still considered as one of the difficult skills for santri in the Pesatren of Nurul Huda 2 Tanah Merah. Many santri face some difficulties when they want to communicate in English, even though they have learned English for many years. As a solution to motivate students to learn and communicate in English, that is by providing attractive teaching media through effective learning methods. In this service the method used is using VAK (Visualization, Auditory, and Kinestetic) media. One of the results and benefits of this service activity is to provide knowledge about the media and English conversation learning methods to increase students' interest in learning and communicating in English every day.
\end{abstract}

Keywords: speaking Ability, Visualization Auditory Kinestetic.

\section{PENDAHULUAN}

Bahasa adalah alat yang digunakan untuk berkomunikasi, baik lisan maupun tulisan menurut (Puskur 2006), Bahasa memiliki peran sentral dalam perkembangan intelektual, sosial, dan emosional peserta didik dan merupakan penunjang keberhasilan dalam mempelajari semua bidang studi. Pembelajaran bahasa diharapkan membantu peserta didik mengenal dirinya, budayanya, dan budaya orang lain. Selain itu, pembelajaran bahasa juga membantu peserta didik mampu mengemukakan 
gagasan, ide, dan perasaan, berpartisipasi dalam masyarakat, dan bahkan menemukan serta menggunakan kemampuan analitis dan imaginatif yang ada dalam dirinya.

Bahasa Inggris adalah bahasa yang banyak digunakan setelah bahasa ibu, tidak hanya menggunakan bahasa yang baku atau bahasa resmi tetapi juga mencakup tentang komunikasi seharihari asalkan mudah dipahami oleh rekan bicaranya. Menurut Waluyo dkk (2010) menyatakan bahwa apabila kemampuan berkomunikasi dianggap sebagai tujuan akhir pembelajaran, maka hendaknya tidak hanya dipandang sebagai produk, tetapi juga sebagai proses. Implikasinya kemampuan berkomunikasi harus diajarkan, karena dengan diajarkannya komunikasi maka kemampuan linguistik juga akan diajarkan. Waluyo (2010) mengemukakan bahwa model pembelajaran di tingkat SMA dan SMA yang berorientasi pada peningkatan kemampuan berkomunikasi siswa sangat penting dilaksanakan.

Bahasa Inggris merupakan bahasa internasional nomor satu yang sering kali digunakan pada setiap pertemuan antar negara, Richards and Rogers, (01: 1986). Selain paling banyak digunakan, juga sangat penting untuk dipelajari mengingat zaman yang semakin maju dan teknologi yang semakin canggih dan modern, selain itu menurut Tri (2003) mengemukakan salah satu peranan bahasa Inggris dalam perkembangan ilmu pengetahuan dan teknologi adalah bahwa ilmu pengetahuan dan teknologi yang berasal dari barat disampaikan dalam bahasa Inggris.akan tetapi demikian tidak semua siswa bisa menguasai bahasa Inggris dengan baik, oleh karena itu banyak siswa Indonesia masih mengalami kesulitan untuk menerapkan ilmu pengetahuan dan teknologi yang berasal dari Barat. dengan demikian harus diakui bahwa bahasa Inggris sangat penting perannya dalam meningkatkan kualitas sumber daya manusia Indonesia terutama untuk mengembangkan ilmu pengetahuan dan teknologi khususnya dikalangan pesantren.

Pada zaman Globalisasi sekarang ini Keunikan pondok pesantren yang hadir dalam dunia pendidikan merupakan budaya yang turun temurun dari seorang kyai kepada santri santrinya. Kriteria kyai ini yang sangat kental di kalangan santri sebagai sosok panutan dan tauladan dari masyarakat. Kyai zaman dahulu memang benar - benar sosok guru dari segala guru yang benar-benar disegani dari mulai tutur kata dan tindakannya. Pondok pesantren zaman dulu masih banyak berkembang sampai sekarang ini dengan santri-santrinya yang bertambah banyak. Oleh karena itu pondok pesantren sekarang ini menjadi dunia pendidikan yang banyak dicari oleh masyarakat sebagai tempat pendidikan putra - putrinya. Pendidikan Pondok pesantren zaman sekarang meluas dimana - mana karena kurikulumnya dan cara pengajarannya yang mulai menyesuaikan dengan kurikulum pendidikan nasional tetapi tanpa menghilangkan karakteristik tradisionalnya.

Di pondok pesantren Nurul Huda II di Tanah Merah ini mempunyai program bilingual yakni bahasa Inggris dan bahsa Arab yang harus diterapkan bagi santriwan dan santriwatinya, yang dilakukan secara bergantian perminggunya, satu minggu menerapkan bahasa inggris dan satu minggunya menerapkan bahasa arab, agar mereka bisa menerapkan program bilingual nya, mereka di gembleng dengan cara diberikan kosakata atau vocabulary setiap hari agar mereka bisa berbicara bahasa inggris dengan lancar dan fluently, karena pada saat ini ada penerimaan siswa baru maka speaking mereka mengalami perubahan drastis, karena mereka belum bisa menyesuaikan dengan siswa lama, oleh karena itu disini akan diadakan pengabdian untuk meningkatkan speaking mereka. Di Pondok Pesantren ini yang lebih ditekankan adalah segi speaking nya atau berbicaranya. Karena program ini diharapkan yang nantinya bisa memunculkan generasi-generasi yang tangguh dalam mendalami bahasa international.

Dari latar belakang tersebut, perlunya peningkatan kemampuan santri-santri untuk mempunnyai keberanian berbicara di depan umum. Pelatihan membangun kemauan berbicara didepan umum ini sangat tepat bagi para santri. Menghilangkan kendala rasa malu, takut dan khawatir berbuat salah perlu dirubah menjadi keberanian dan kepercayaan diri serta rasa tertarik untuk mampu melakukan. Oleh karena itu, kami berupaya melatih para santri di pondok pesantren ini agar supaya para santrinya memiliki kemauan dan ketertarikan berbicara didepan umum dengan menggunakan bahasa Inggris 
yang menjadi target pembelajaran bahasa Inggris sesuai dengan apa yang diharapkan oleh masyarakat atau orang tua para santri.

\section{SOLUSI METODE}

Solusi dari pengabdian kepada masyarakat ini adalah dengan cara memberikan pelatihan, praktek dan memberikan kosa kata bahasa Inggris yang dibutuhkan oleh para santri dan diharapkan bisa meningkatkan berbicara bahasa Inggris mereka sehari-hari. Metode pembelajaran merupakan salah satu faktor penting yang mempengaruhi proses kegiatan belajar mengajar, oleh karena itu sangatlah perlu sekali diterapkan untuk meningkatkan kualitas belajar peserta didik, dengan bagusnya metode pembelajaran yang diterapkan kepada peserta didik akan menimbulkan kesemangatan belajar, sehingga bisa memunculkan nilai yang diharapkan pula. Salah satu metode pembelajaran yang bisa digunakan yaitu dengan menggunakan metode VAK (visualization,auditory and kinestetic). Metode pembelajaran VAK merupakan metode pembelajaran yang mengoptimalkan ketiga modalitas yang dibutuhkan bagi pendidik dan peserta didik merasa nyaman dalam belajar. Metode VAK menggunakan tiga macam sensori dalam menerima informasi yaitu penglihatan, pendengaran dan gerakan. Pembelajaran dengan metode VAK mengutamakan pengalaman belajar secara langsung dan menyenangkan bagi peserta didik. Pengalaman belajar secara langsung dengan cara belajar dengan mengingat, belajar dengan mendengar, dan belajar dengan gerak dan emosi.

Colin Rose dan Malcolm J Nichol menyatakan bahwa ada metode pembelajaran dan komunikasi yang menjadi pedoman dasar dalam metode VAK adalah sebagai berikut:

a. Visual (belajar dengan cara melihat) Belajar harus menggunakan indera mata melalui mengamati,menggambar, mendemonstrasikan, membaca, menggunakan media dan alat peraga. Seorang peserta didik lebih suka melihat gambar atau diagram, suka pertunjukan, peragaan atau menyaksikan video. Bagi peserta didik yang bergaya belajar visual, yang memegang peranan penting adalah mata/penglihatan (visual).

b. Auditori (belajar dengan cara mendengar) Belajar haruslah mendengarkan, menyimak, berbicara, presentasi, mengemukakan pendapat, gagasan, menanggapi dan beragumentasi. Seorang peserta didik lebih suka mendengarkan kaset audio, ceramah, diskusi, debat dan instruksi (perintah) verbal. Alat rekam sangat membantu pembelajaran pelajar tipe auditori. Merekomendasikan setelah membaca sesuatu yang baru, deskripsikan dan ucapkan apa yang sudah dibaca tadi sambil menutup mata dengan suara lantang. Alasannya setelah dibaca, divisualisasikan (ketika mengingat dengan mata tertutup) dan dideskripsikan dengan lantang, maka secara otomatis telah belajar dan menyimpannya dalam multisensori. Ciri-ciri peserta didik yang lebih dominan memiliki gaya belajar auditori misalnya lirikan mata ke arah kiri/kanan, mendatar bila berbicara dan sedang-sedang saja. Untuk itu, guru sebaiknya harus memperhatikan peserta didiknya hingga kealat pendengarannya.

c. Kinestetik (belajar dengan cara bergerak, bekerja dan menyentuh) Belajar melalui aktivitas fisik dan keterlibatan langsung. Seorang peserta didik lebih suka menangani, bergerak, menyentuh dan merasakan/mengalami sendiri, gerakan tubuh (hands-on, aktivitas fisik). Bagi peserta didik kinestetik belajar itu haruslah mengalami dan melakukan. Ciri-ciri peserta didik yang lebih dominan memiliki gaya belajar kinestetik misalnya lirikan mata ke bawah bila berbicara dan berbicara lebih lambat. Anak seperti ini sulit untuk duduk diam berjam-jam karena keinginan mereka untuk beraktifitas dan eksplorasi sangatlah kuat. Peserta didik yang bergaya belajar ini, belajarnya melalui gerak dan sentuhan.

\section{HASIL DAN DISKUSI}


Kegiatan pengabdian ini dilaksanakan dengan cara tatap muka dan penggunaan media belajar melalui metode demonstrasi, ceramah dan diskusi, kemudian dilanjutkan dengan latihan praktek vocabulary, conversation, debate etc. kegiatan ini dilaksanakan selama 10 hari dari pukul15.30-17.00 WIB. Peserta kegiatan berjumlah 24 orang dan lokasi penyelenggara pengabdian ini Pondok Pesantren Nurul Huda Tanah Merah 2.

Keterbatasan waktu membuat tidak sepenuhnya materi tersampaikan dengan detail sehingga para santri masih mengharapkan keberlanjutan dari kegiatan pengabdian ini. Namun dengan pertemuan yang terbatas ini diharapkan para santri bisa lebih fluently, enjoy dan dapat mengaplikasikan serta mengembangkan apa yang sudah didapat dari pengabdian ini dalam kegiatan sehari-hari.

Hasil kegiatan ini akan bermanfaat bagi sekolah dan pondok pesantren. Proses belajarnya akan lebih bervariasi dan menjauhkan santri dari bored situation. Disamping itu dengan adanya kegiatan ini akan menambah skill para santri mengolah kemampuannya dalam berbahasa asing.

\section{PEMBAHASAN}

Secara garis besar cakupan hasil dari kegiatan pengabdian ini adalah sebagai berikut:

1. Tujuan pengabdian

2. Target materi

3. Kemampuan Santri

Tingkat ketercapaian pengabdian ini secara umum sudah baik tetapi dengan terbatasnya waktu membuat tidak semua materi tersampaikan dengan detail, namun jika dilihat dari hasil pengabdian maka dapat disimpulkan tujuan dari kegiatan dapat tercapai. Ketercapaian target materi pada kegiatan pengabdian ini terhitung baik, karena materi sudah dapat disampaikan secara keseluruhan. Kemampuan santri terbilang sudah bagus dengan basic bahasa yang sudah matang, kemudian pengabdian ini mentargetkan berkembangnya kemampuan santri dalam berbicara bahasa inggris secara continue.

Di pondok pesantren Nurul Huda Tanah Merah para santri diberikan kegiatan yang beraneka ragam setelah selesai mengikuti kegiatan formal di sekolah masing-masing, santri di beri opsi memilih kegiatannya yakni kursus bahasa arab, bahasa inggris dan ngaji bandongan dengan abah Yai, target peserta pengabdian ini awalnya direncanakan 30 santri putri, dalam pelaksanaannya pengabdian ini diikuti oleh santri putra dan putri dengan jumlah 24 orang. Keadaan ini, bisa disebut kurang memenuhi ekspektasi diawal. Namun tidak mengurangi tujuan dari pada pengabdian ini.

Secara keseluruhan kegiatan pengabdian ini dapat dikatakan berhasil. Keberhasilan ini selain diukur dari beberapa komponen yang telah disebutkan juga dilihat dari kepuasan dan juga permintaan tambahan waktu pengabdian dari para santri.

\section{SIMPULAN}

Program pengabdian ini dapat terselenggara dengan baik dan lancar sesuai dengan rencana yang telah disusun, kegiatan ini mendapat respon yang sangat baik, terbukti dari antusias dan keaktifan peserta mengikuti kegiatan pengabdian ini dengan meminta tambahan waktu pertemuan dan tidak meninggalkan tempat sebelum waktu pengabdian berakhir.

\section{UCAPAN TERIMAKASIH}

Terima kasih yang tak terhingga kepada Ketua STKIP Nurul Huda Sukaraja dan Ketua LPPM STKIP Nurul Huda Sukaraja yang telah memberikan kesempatan kepada kami dalam melaksanakan pengabdian dengan menerbitkan nomor kontrak pengabdian 017/STKIP-NH/LPPM/XI/2018, sebagai salah satu bentuk Tri darma perguruan tinggi di STKIP Nurul Huda Sukaraja, terima kasih juga kepada anggota Jurnal Indonesia Mengabdi STKIP Nurul Huda Sukaraja, Pengasuh pondok Pesanten Nurul 
Huda 2 Tanah Merah yang telah membantu mewujudkan kegiatan pengabdian ini dengan mengizinkan kami melaksankan kegiatan di lingkungan pesantren dan kepada semua dosen di lingkungan STKIP Nurul Huda terima kasih atas support dan bantuan moril sehingga pengabdian ini bisa berjalan dengan baik dan lancar.

\section{DAFTAR PUSTAKA}

Bobbi D., Mike H. (2011), Quantum Learning, Bandung: Kaifa.

Colin R., Malcolm J. Nicholl,( 2009), Accelerated Learning, Bandung: Nuansa.

Puskur Balitbang Depdiknas.(2006). Draft Panduan Penyusunan Kurikulum Dan Silabus Bervisi Sets (Salingtemas) Tingkat Satuan Pendidikan Dasar Dan Menengah. Jakarta: Puskur Balitbang Depdiknas.

Richards and Rogers, (1986). approachers and methods in language teaching, Jakarta: Cambridge University Press.

Tri, W. (2003). Mencerna Buku Teks Bahasa Inggris Melalui Pemahaman Gramatika.Yogyakarta: Pustaka Pelajar.

Waluyo, K., \& Joko, N. (2010). Kemampuan dosen Mengimplementasikan Pendekatan Komunikatif dalam Pengejaran Bahasa Inggris di SMA dan SMK Kota Surakarta. Jurnal Penelitian Paedagogia. Hal, 87-97. 